\title{
The Effectiveness of Ultrasonography in Detecting Emergent Pediatric Pathologies and Requirement for Additional Imaging Techniques: A Retrospective Study
}

\author{
Çocuk Acil Patolojilerin Saptanmasında Ultrasonografinin Etkinliği: Tanı Aşamasında \\ Bilgisayarlı Tomografi Gibi Ek Görüntüleme Gerekli midir? Geriye Dönük Çalışma
}

\author{
(D) Betül Tiryaki Baştuğ \\ Eskişehir Osmangazi University Faculty of Medicine, Department of Radiology, Eskişehir, Turkey
}

\section{Abstract}

Introduction: In emergency cases, ultrasonography is used in guiding resuscitation, to provide procedural guidance, and confirm a clinical diagnosis. In addition, it may prevent unnecessary exposure of the patient to ionizing radiation and risks caused by transporting the patient away from monitoring. This paper aimed to evaluate the effectiveness of ultrasonography in detecting emergent pediatric pathologies in a state hospital radiology unit, and to identify whether additional imaging techniques, such as computed tomography, were required.

Methods: This study was designed as a retrospective investigation. A group of 536 patients were randomly selected from 1.401 pediatric patients who underwent ultrasonography for non-traumatic emergent pathologies between 2015 and 2016.

Results: Of the 536 patients, 46 were diagnosed with appendicitis, 14 with pathologies of the urinary system, 1 with ileus, 29 with mesenteric lymphadenitis, 4 with intussusception, 3 with ovarian cyst rupture, 1 with ovarian torsion, and 32 with scrotal pathologies. Computed tomography was performed for 20 patients. Ureteral calculi and appendicitis were confirmed by computed tomography in 5 and 14 patients, respectively, after being identified as secondary findings by ultrasonography. In 1 patient, ileus was verified by computed tomography. The sensitivity of ultrasonography was determined to be $85.7 \%$. Only $14 \%$ of patients were not given definite pathological diagnoses by ultrasonography alone. Subsequent computed tomography for verifying secondary findings detected by ultrasonography was essential in only 20 patients.

Conclusion: Our results promote the use of ultrasonography as the initial imaging test for evaluating pediatric patients with suspected emergency pathologies.

Keywords: Ultrasonography, pediatric emergent pathologies, computed tomography, ionizing radiation, cancer

\section{Öz}

Amaç: Acil şartlarda ultrason, resüsitasyonu yönlendirmek ve prosedürel rehberlik sağlamak amacıyla kullanılır. Ayrıca geleneksel görüntüleme modalitelerinin çok uzun süre alacağı hastalarda ya da hastayı izlem ortamından uzaklaştırma sebebiyle ya da iyonize radyasyona maruz bırakmak suretiyle ortaya çıkabilecek riskleri ortadan kaldırma amacı ile de kullanılabilir. Çalışmamızın amacı bir devlet hastanesinde radyoloji ünitesinde ortaya çıkan çocuk acil patolojilerin saptanmasında ultrasonografinin etkinliğini değerlendirmek ve bilgisayarlı tomografi gibi ek görüntülemenin gerekip gerekmediğini saptamaktır.

Yöntemler: Çalışma geriye dönük bir araştırma olarak tasarlandı. 2015-2016 yılları arasında acil patolojiler için sonografi uygulanan 1401 çocuk hasta arasından rastgele 536 hasta seçildi.

Bulgular: Kırk altı hastada apandisit, 14 hastada idrar yolu patolojisi, 1 hastada ileus, 29 hastada mezenterik lenfadenit, 4 hastada intussusepsiyon, 3 hastada over kist rüptürü, 1 hastada over torsiyonu, 32 hastada skrotal patolojiler saptanmıştır. Yirmi hastada bilgisayarlı tomografi yapılmıştır. Bilgisayarlı tomografide beş hastada üreter taşı ve önceki ultrasonografide sekonder bulgularla düşünülen 14 hastada apandisit tespit edildi. Bir hastada ileus bilgisayarlı tomografide doğrulanmıştır. Ultrasonun test hassasiyeti değeri \%85,7 olarak hesaplandı. Hastaların sadece \%14'üne ultrason ile kesin patolojik tanı konamamıştır. Ultrasonografide saptanan ikincil bulguları doğrulamak için sadece 20 hastada bilgisayarlı tomografi gerekliydi.

Sonuç: Acil patolojilerden şüphelenilen çocuk hastaların değerlendirilmesinde ultrason ilk tercih edilen görüntüleme modalitesi olmalıdır.

Anahtar Kelimeler: Ultrasonografi, çocuk acil patolojiler, bilgisayarlı tomografi, iyonlaştırıı radyasyon, kanser

Address for Correspondence/Yazışma Adresi: Betül Tiryaki Baştuğ MD, Eskişehir Osmangazi University Faculty of Medicine, Department of Radiology, Eskişehir, Turkey

E-mail: betultryak@yahoo.com ORCID ID: orcid.org/0000-0001-7793-7887

Received/Geliş Tarihi: 23.10.2017 Accepted/Kabul Tarihi: 10.01.2018

The study was presented as a poster at the European Congress of Radiology 2017 congress in Vienna.

- Copyright 2018 by Society of Pediatric Emergency and Intensive Care Medicine

Journal of Pediatric Emergency and Pediatric Intensive Care published by Galenos Yayınevi. 


\section{Introduction}

Ultrasonography (USG) is increasingly being used to speed up patient care and avoid exposure to ionizing radiation. ${ }^{1}$ USG is used in a wide variety of specialties, and their use has increased in the last decade as USG machines become more compact and portable. USG is used for a variety of examinations. It can be performed in various clinical settings at the patient's bedside. It can be used to guide resuscitation and to monitor critically ill patients in an emergency setting. It provides procedural guidance for improved safety. It can assist in confirming clinical diagnoses that would take too long via conventional diagnostic methods or that would introduce more significant risk to the patient, either by transporting them away from a closely monitored setting or by exposing them to ionizing radiation. Abdominal pain is a common complaint in emergency departments. Trauma, appendicitis, and intussusception are the most common reasons for abdominal imaging in emergent pediatric patients. ${ }^{2}$ Many doctors use USG for the diagnosis of other urgent and emergency problems, including testicular and ovarian torsion, ovarian cyst rupture, and strangulated hernia.

Computed tomography (CT) is an imaging method that uses X-rays to create cross-sectional images. Despite its advantages, CT uses ionizing radiation, which has the potential to cause cancer. This risk increases when numerous additional scans are performed. However, CT may be performed if the benefits greatly outweigh the risks. As radiation-induced cancer takes years to develop; it is particularly important to minimize unnecessary CT scans in younger patients. However, many physicians do not consider this while ordering CT. In most emergency departments, the use of magnetic resonance imaging (MRI) as a primary modality for the evaluation of a child with abdominal pain remains impractical due to the high cost and limited availability. The need for sedation is another problem. USG does not involve ionizing radiation and, unlike MRI, is relatively inexpensive, widely available, and does not require sedation. Another significant advantage of USG in abdominal imaging is that it allows for the dynamic assessment of bowel peristalsis and compressibility.

The aim of the present paper was to evaluate the effectiveness of USG in detecting emergent pediatric pathologies in a state hospital radiology unit and to determine whether additional imaging methods, such as $\mathrm{CT}$, were required for diagnosis.

\section{Materials and Methods}

The study was designed as a retrospective investigation. A total of 536 pediatric patients ( 284 males, 252 females) were randomly selected from a pool of 1.401 pediatric patients who had been examined clinically followed by standardized USG for emergent pathologies between 2015 and 2016. USG was performed and reported in the radiology department by radiologists with at least 10 years of radiology experience. Trauma patients were not included in the study as the hospital where the work was performed was not a trauma center, and there were no pediatric intensive care facilities. Most pediatric trauma patients were referred to other hospitals for pediatric intensive care. Furthermore, the limited trauma USG experience of the radiologists in our unit could have increased the rate of false-positive USG results and the number of CTs, which would have influenced the results of this study.

\section{Study Analysis}

In the data analyses, descriptive statistics were calculated and presented with frequency and percentage values. Truepositive, true-negative, false-positive, and false-negative rates were calculated by cross-tabulation in the patients diagnosed using USG, and the overall diagnostic sensitivity was calculated for all patients. Analyses were performed with SPSS 22.0 software. The images were created with Microsoft Excel 2017 software. The study was presented as a poster at the 2017 European Congress of Radiology in Vienna.

\section{Results}

Abdominal pain and vomiting were the most common clinical symptoms. In the study group, patient age ranged from 0 to 17 years. In the study, 13 patients were under 1 year of age, 106 patients were 1, and under seven years old, 284 patients were 7 and under 15 years old, 133 patients were 15 years old and over (Figure 1). Appendicitis was detected in 46 patients. Mesenteric lymphadenitis was identified in 29 patients. Three patients were diagnosed with hydrocele, 4 had epididymitis, and 1 had testicular torsion. Hydronephrosis was detected in 14 patients, and it was found to be caused by ureteral calculi. Intussusception was identified in 4 patients. In 3 patients with ruptured ovarian cysts and one patient with ovarian torsion, secondary findings were observed via USG. The majority of patients ( $n=426)$ had normal USG results (Figures 2 and 3 ). A CT examination was performed in 20 patients (Figure 4).

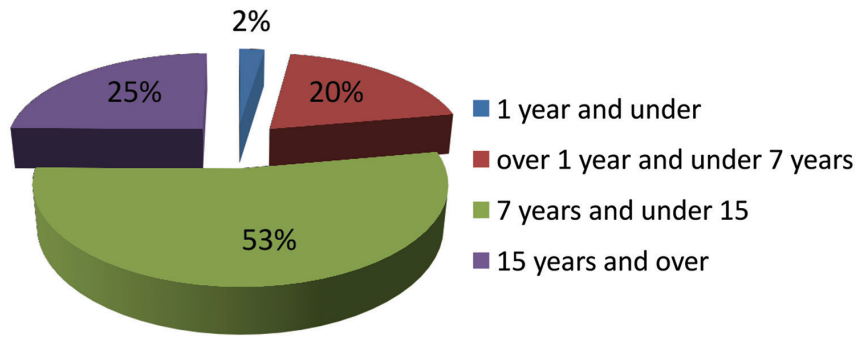

Figure 1. Distribution of patients according to age 
Five patients were confirmed as having ureteral calculi and 14 patients were confirmed as having appendicitis by $\mathrm{CT}$ after detection as secondary findings by USG. In 1 patient, ileus was verified by $\mathrm{CT}$. For these non-traumatic emergent pediatric pathologies, the sensitivity of USG was calculated as $85.7 \%$. Only $14 \%$ of patients were not given definite pathological diagnoses with USG (Table 1).

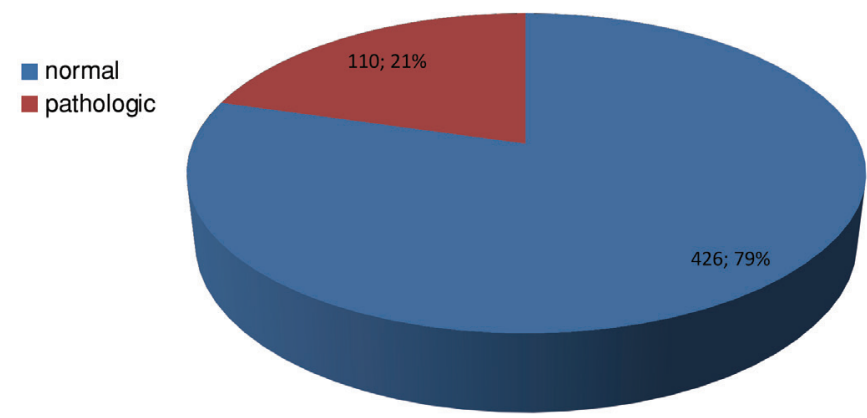

Figure 2. Distribution of patients according to normal-pathologic
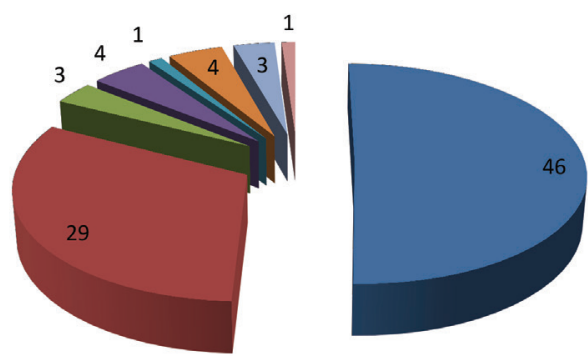

- Appendicitis

Mesenteric lymphadenitis

whdrocele

a epididimit

mesticular torsion

- intussusception

In ovarian cyst rupture

movarian torsiyon

Figure 3. Distribution of patients according to pathology

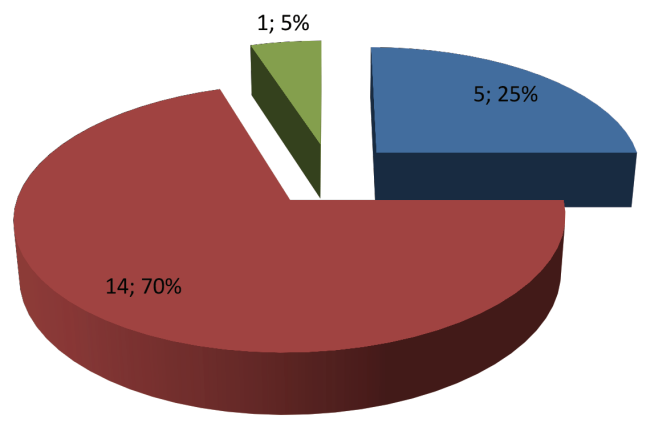

ureteral calculi

appendicitis

n ileus

Figure 4. Distribution of patients according to pathology on computed tomography exam

Table 1. Measurement of ultrasound precision diagnostic sensitivity

\begin{tabular}{|lll|} 
Grup & Definitely diagnosed (\%) & Not identified (\%) \\
Pathology (+) & $130(24 \%)$ & $20(4 \%)$ \\
Pathology (-) & $0(0 \%)$ & $386(71 \%)$ \\
$\begin{array}{l}\text { The test sensitivity value was calculated as } 85.7 \% . \text { According to this, } 14 \% \text { of the } \\
\text { patients were not given definite pathological diagnoses with ultrasound }\end{array}$ \\
\hline
\end{tabular}

\section{Discussion}

USG has many advantages over other radiological imaging methods, especially in emergency departments. It is an inexpensive and non-invasive way of imaging. There is no pain associated with the procedure, it can be formed with ease, and it can be performed immediately at the bedside of a very ill patient. There are no risks associated with repeating USG several times; the absence of ionizing radiation is the main advantage of USG over other imaging techniques, especially CT. We know well the bad effects of radiation associated with CT. Therefore, in pediatric emergency departments, USG is being adopted as the imaging method of choice. However, the greatest disadvantage is that the correct sonographic diagnosis often depends on the operator.

Focused assessment with USG for trauma (FAST) is a technique that can quickly be applied at the bedside. It is used to detect free abdominal fluid. The right upper quadrant, the left upper quadrant, the pericardium, and the pelvis are examined for free fluid. Detection of free fluid is identified as a positive FAST. While unstable patients are being evaluated, the application time of radiological techniques become important. USG saves time when trying to detect injury before an operation. Cost effectiveness is another important point for patient care when comparing USG with diagnostic peritoneal lavage or CT.

Intussusception can be a reason for bowel obstruction in children. It occurs when a part of the intestine invaginates into a distal portion of the bowel. ${ }^{3}$ The symptoms are nausea, vomiting, cramping, abdominal pain, and rectal bleeding that is commonly described as "red currant jelly". These patients are mostly between 6 months and 2 years of age. Early diagnosis improves the prognosis. USG has a high sensitivity of $98-100 \%$ and specificity of $88-100 \%$. On an USG, intussusception appears in the shape of "target" or "donut", made by the intussuscipiens (receiving bowel loop) and the proximal intussusceptum (prolapsing bowel loop), with echogenic intervening mesenteric fat. Another USG appearance that has been described is the "pseudokidney" sign. It is made by fat-containing mesentery and vessels that are dragged into the intussusception. It looks like the renal hilum, with the apparent renal parenchyma formed by the surrounding edematous bowel. USG is also able to detect lymph nodes, polyps, duplication cysts and Meckel's diverticulum. Trapped fluid within the intussusception and absence of blood flow to the bowel on Doppler USG are the signs of ischemia. These points decrease reducibility. In some institutions, USG-guided hydrostatic pressure is performed for successful reduction.

Appendicitis is the most common childhood surgical emergency. ${ }^{4}$ Diagnosis is challenging, especially in younger children, because of the potential for a false-negative 
diagnosis and because of the potential for perforation and other complications. Imaging studies can reduce the number of negative appendectomies. USG has a sensitivity of $88 \%$ and specificity of $94 \%$ according to a meta-analysis of studies conducted from 1986 to 2004. A high-frequency linear transducer is used for USG to evaluate the appendix. Compression can be helpful because normal bowel loops can be displaced from the right lower quadrant by this way. Just lateral to the cecum and anterior to the iliac vessels is the common position of an appendix. A diameter greater than $6 \mathrm{~mm}$, a non-compressible lumen arising from the base of the cecum, echogenic changes in periappendiceal fat caused by inflammation, an appendicolith, or periappendiceal fluid collection are suggestive of appendicitis. Enlarged mesenteric lymph nodes or signs of a perforated appendix, such as abscess, can also be seen on USG.

USG is the primary imaging technique for evaluating acute scrotal pathologies in children. ${ }^{5}$ Testicular torsion, testicular appendage torsion, epididymitis, orchitis, hernia, hematocele, and abscess are the most common pediatric scrotal presentations seen in emergency departments. To distinguish these disorders, establish a correct diagnosis, and start treatment, it is vital to know standard characteristics of the disorders and pitfalls of diagnosis.

USG is usually preferred for the evaluation of the pelvis in female children in order to exclude or diagnose emergency conditions such as pelvic abscess, ovarian torsion, or an ectopic pregnancy. ${ }^{6} \mathrm{~A}$ failure during a menstrual cycle causes functional follicular ovarian cysts. A functional ovarian cyst may imitate acute appendicitis because of the pain as the resulting bleeding or rupture. Avascular, anechoic, thinwalled mass with posterior acoustic enhancement is thought of as a non-complicated ovarian cyst. Most cysts are small and do not require treatment. However, some may be large and require follow-up. Hemorrhagic cysts are usually seen as a "lace-like pattern" on USG because of septations and internal echoes. The main appearance depends on the age of the blood.

Pancreas and biliary systems are well-assessed with USG in emergency departments. ${ }^{7}$ Sonographic findings of the pancreatitis in children are similar to adults, and they include diffuse or focal, usually hypoechoic, pancreatic enlargement and dilatation of the pancreatic duct. The primary complications are pseudocyst, pancreatic abscess, necrosis, and hemorrhage. However, the causes are different in pediatric patients, and are usually idiopathic; pediatric pancreatitis can be related to trauma or congenital structural anomalies. Pyelonephritis, ureteropelvic junction obstruction, and rarely nephrolithiasis are the frequent pediatric renal causes of abdominal pain. ${ }^{8}$
In the emergency radiology department, cranial USG is used not only to exclude parenchymal pathology such as hemorrhage, hydrocephalus, or a tumor of an open anterior fontanelle in a baby with a growing head circumference, but it is also used to separate the benign enlargement of subarachnoid spaces (BESS) from subdural collections and hematomas. BESS means excessive cerebrospinal fluid (CSF) accumulation in the subarachnoid regions in infants, especially in the frontal areas. ${ }^{9}$

USG can be used to detect joint effusions, particularly of the hip, to guide percutaneous drainage and to localize nonradiopaque foreign bodies for musculoskeletal emergencies in pediatrics. ${ }^{10}$

As with the literature, our study confirmed that USG has many applications in the evaluation of pediatric patients who present to the emergency department with traumatic or nontraumatic emergencies. In the emergency department, USG can be performed rapidly and easily. Another main advantage is the absence of ionizing radiation. We can image both stable and unstable pediatric patients and make or exclude a diagnosis.

\section{Study Limitations}

One of the limitations of the present study is that trauma patients were not included in the study. As the hospital in which the patients were treated is not a trauma center and there are no pediatric intensive-care facilities, most children were referred to other hospitals for pediatric intensive care. Another related issue was the limited experience of the radiologists on trauma USG, which could have increased the number of CTs and influenced the results of the study.

\section{Conclusion}

The results of our study suggest that USG should remain the first imaging test of choice for evaluating pediatric patients with suspected emergency pathologies. The advantages of USG imaging are that the procedure can be performed quickly and at the bedside, it does not involve exposure to x-rays, and it is relatively inexpensive compared to other frequently used techniques, such as abdominal $\mathrm{CT}$. For detecting pediatric emergent pathologic disorders, the disadvantage of USG arises when there is a lot of gas present inside the bowels or excess abdominal fat, which makes imaging difficult, and the quality of the images depend on the experience of the person performing the USG. However, USG imaging occurs in real-time and does not require sedation, so the influence of movements can be assessed quickly. Through the abdominal wall, pelvic organs, such as the urinary bladder and the ovaries, can be seen. We found that although USG was less sensitive 
than CT for the diagnosis of nephrolithiasis, using USG as the initial test in patients with suspected nephrolithiasis was definitive enough that there was no need for $C T$ in most patients and, thus, lower cumulative radiation exposure. Furthermore, there were no significant differences in the risk of subsequent adverse events, pain scores, return visits to the emergency department, or hospitalizations. Abdominal CT comes with radiation exposure, a high rate of incidental findings that can lead to inappropriate followup referral and treatment, and added cost. Doctors should consider whether some scans are doing more harm than good, and must take this into account when deciding whether a CT scan is required.

\section{Ethics}

Ethics Committee Approval: Ethics committee approval was obtained from Bilecik State Hospital.

Informed Consent: Retrospective study.

Peer-review: Externally and internally peer-reviewed.

Conflict of Interest: No conflict of interest was declared by the author.

Financial Disclosure: The author declared that this study received no financial support.

\section{References}

1. Vasavada P. Ultrasound evaluation of acute abdominal emergencies in infants and children. Radiol Clin North Am. 2004;42:445-56.

2. Strouse PJ. Sonographic evaluation of the child with lower abdominal or pelvic pain. Radiol Clin North Am. 2006;44:911-23.

3. Kairam N, Kaiafis C, Shih R. Diagnosis of pediatric intussusception by an emergency physician-performed bedside ultrasound: a case report. Pediatr Emerg Care. 2009;25:177-80.

4. Doria AS, Moineddin R, Kellenberger CJ, Epelman M, Beyene J, et al. US or CT for diagnosis of appendicitis in children and adults? A meta-analysis. Radiology. 2006;241:83-94.

5. Frush DP, Sheldon CA. Diagnostic imaging for pediatric scrotal disorders. Radiographics. 1998;18:969-85.

6. Stranzinger E, Strouse PJ. Ultrasound of the pediatric female pelvis. Semin Ultrasound CT MRI. 2008;29:98-113.

7. Nievelstein RA, Robben SG, Blickman JG. Hepatobiliary and pancreatic imaging in children-techniques and an overview of nonneoplastic disease entities. Pediatr Radiol. 2011;41:55-75.

8. Brader P, Riccabona M, Schwarz T, Seebacher U, Ring E. Value of comprehensive renal ultrasound in children with acute urinary tract infection for assessment of renal involvement: comparison with DMSA scintigraphy and final diagnosis. Eur Radiol. 2008;18:2981-9.

9. Zahl SM, Egge A, Helseth E, Wester K. Benign external hydrocephalus: a review, with emphasis on management. Neurosurg Rev. 2011;34:417-32.

10. Bianchi S, Martinoli C. Ultrasound of the musculoskeletal system. Berlin: Springer; 2007. 